\title{
Fears for fading fireflies prompt online monitor
}

Firefly researchers swarmed to Chiang Mai,

Thailand, in August for a symposium on their

favourite beetle and to enjoy the creatures'

famous light show on the banks of the Mae

Klong River.

But the display here, and elsewhere across the

world, has lost a certain lustre because the fireflies

seem to be disappearing. To improve on the mostly

anecdotal data for firefly declines, the Boston Museum of

Science in Massachusetts, in conjunction with researchers at

Tufts University in Medford and Fitchburg State College, has

developed Firefly Watch (https://www.mos.org/fireflywatch),

an online tracking system to which volunteers can contribute

data. The site has collected 11,000 data points since May.

\section{China pauses on turning coal into liquid fuel}

The Chinese government has issued a temporary moratorium on new facilities for converting coal into liquid transportation fuels, although at least two of the biggest projects will still move forward.

The moratorium would allow the stateowned Shenhua Group to build a plant in Inner Mongolia and continue a project with the South African energy giant Sasol. But the broader effects of the policy are unclear for an estimated six other plants reportedly under construction.

Chinese companies have been pursuing coal-converting technologies for a range of products, from chemicals to liquid fuels, to reduce China's reliance on imported crude oil. Industry officials say coal-based chemical production will continue and suggest that the current policy does not necessarily represent a definitive shift away from coal-to-liquid technologies.

\section{Wellcome Trust goes into partnership with India}

The Indian government has approved a ten-year, $\mathfrak{E 1 6 0 - m i l l i o n ~ ( U S \$ 2 8 0 - m i l l i o n ) ~}$ partnership between its Department of Biotechnology and the Wellcome Trust, a medical-research charity based in London, UK, to fund biomedical research in India.

Operated as an independent, charitable trust based in New Delhi, the new alliance will award research fellowships to an estimated 700 researchers over ten years. It was announced on 4 September that the two parties will each contribute $50 \%$ to the programme.

"The programme will result in a strong, world-class human-resource foundation ... at a scale where the country can make a global impact," according to the cabinet statement.

Maharaj Kishan Bhan, secretary of the biotechnology department, says that it is the most ambitious scheme ever launched by India to reverse the brain drain.

\section{Correction}

In the News Feature 'The long summer begins' (Nature 454, 266-269; 2008), the photograph of divers on page 268 should have been credited to Jeremy Stewart not Doug Barber. 